Aleksandra KANIEWSKA-SĘBA

DOI : $10.14746 /$ pp.2017.22.3.4

\title{
Beata PAJAZK-PATKOWSKA
}

Adam Mickiewicz University in Poznań

\section{Negative recommendation in social media - theoretical approach and case studies}

\begin{abstract}
The Internet, including the social media services, has considerably changed the manner in which consumers voice favourable or unfavourable recommendations about products and services. Development of social media allowed reaching a significantly greater number of persons in a quicker way. One may also notice that the range of thematic comments has been expanded - customers speak not only about the quality of the products, their prices, service levels, but also about other aspects of how marketing companies function. Finally, it is worth paying attention to the language of these opinions, which - in the case of a negative experience with a product or retailer advertising - is often aggressive.

With the development and dissemination of social networking, PR and marketing communications managers must learn how to communicate and satisfy customers and those who express their discontent at different stages of the purchase funnel. This is especially important in the case of negative word of mouth (NWOM) because every negative opinion can become the nucleus of major problems within brand image and the brand crisis.

The aim of the article is to show the specificity of word of mouth in social media (sWOM) as one of the forms of electronic word of mouth (eWOM) and to depict phenomenon of NWOM in social media basing on selected case studies from the Polish market.
\end{abstract}

Key words: word of mouth (WOM), positive word of mouth (PWOM), negative word of mouth (NWOM), social media

\section{Introduction}

D evelopment of the Internet, including the social media services, has considerably changed the manner in which consumers voice favourable or unfavourable recommendations about products and services. In the past, customers were sharing their opinions with a limited number of people - mostly with the family members, relatives and friends. Development of social media allowed reaching a significantly greater number of persons in a quicker way. One may also notice that the range of thematic comments has been expanded - customers speak not only about the quality of the products, their prices, service levels, but also about other aspects of how marketing companies function, e.g. a limited product availability, advertising campaigns or pro-social issues. Finally, it is worth paying attention to the language of these opinions, which - in the case of a negative experience with a product or retailer advertising - is often aggressive. What is more, the question arises whether it is possible to describe this type of phenomena adopted for years in the marketing literature with the term "negative word of mouth" (NWOM), or whether we need to talk about "hate speech"? 
Word of mouth (WOM) has been a subject of interest for researchers and practitioners in the area of marketing for decades. With the development of the Internet, a new phenomenon has appeared - electronic word of mouth (eWOM), also known as online word of mouth (oWOM). As the results of research conducted by Trusted Trader Internet users attach great importance to opinions and comments found on the Internet. According to information gathered by Trusted Trader, 92 percent of Internet users read opinions about people, products and companies that interest them, 78 percent of them check information about the person or the company before starting cooperation, and 70 percent believe in recommendations published by completely unknown persons. In comparison, only three out of ten trust the opinions posted on the official website of the company (Szklarski, 2014). Consequently, research and business practices since several years focus on the specificity, conditions, possibilities and limitations of eWOM. In particular, due to growing popularity of social media (2.7 billion users in the world), more and more attention in the marketing literature is devoted to WOM in those communication channels (sWOM).

With the development and dissemination of social networking, PR and marketing communications managers must learn how to communicate and satisfy customers and those who express their discontent at different stages of the purchase funnel. This is especially important in the case of negative word of mouth (NWOM) because every negative opinion can become the nucleus of major problems within brand image and the brand crisis.

The aim of the article is to show the specificity of word of mouth in social media (sWOM) as one of the forms of electronic word of mouth (eWOM) and to depict phenomenon of NWOM in social media basing on selected case studies from the Polish market.

\section{The essence of word of mouth}

Word of mouth (WOM) has been named "the world's most effective, yet least understood marketing strategy" (Misner, 1999 after: Trusov, Bucklin, Pauwels, 2009, p. 90). At first, the researchers were defining the notion as a recommendation of the opinionmakers (Katz, Lazarsfeld, 1955 after: Pauwels, Aksehirli, Lackman, 2016, p. 640). Later it was extended so as to comprise "informal communications directed at other Consumers about the ownership, usage, or Particular characteristics of goods and services or their sellers" (Westbrook, 1987, p. 261). Today, the concept of WOM includes the opinions of family members, friends or simply other consumers (Childers, Rao, 1992, pp. 198-211; Godes, Mayzlin, 2005, pp. 545-560; Narayan, Rao, Saunders, 2011, pp. 368-384) and is seen as a key success factor in business, often more important than paid marketing.

We can distinguish primary and secondary WOM. The first refers to opinions, which are the result of direct consumer experience with the product. Meanwhile, the secondary WOM is information provided by customers, whose opinions about a product, service, shop etc. are based on the experiences of other people (Hornik, Satchi, Cesareo, Pastore, 2015, p. 273). Understanding of secondary WOM is important, as it is believed to cover over $70 \%$ of the online WOM (Meiners, Schwarting and Seeberger, 2010). 
Researchers associate WOM communication mechanisms with dissemination of rumours (Westrbrook, 1987) because both phenomena "involve multiple actors and target, have a multi-directional flows of influence and follow an iterative and assimilative process That Develops over time" (Hornik, Satchi, Cesareo, Pastore, 2015, p. 274). In the process of transmission of information (rumours), people seem to believe in a more negative rather than positive news. Negative stories spread faster and on a larger scale. Moreover, the quality of the information may change (Royzman, Rozin, 2001, pp. 296-320). Consumers generally exaggerate the bad information (DiFonzo, Bourgeois, Suls, Homan, Stupak, Brooks, Ross, Bordia, 2013, pp. 378-399). The process resembles rolling a snowball: upon receiving a negative information, people have a tendency to "perseverate, mull it over, talk about it endlessly and explore in fantasy all possible consequences" (Allport, Postman, 1947, p. 154 after: Hornik, Satchi, Cesareo, Pastore, 2015, p. 274).

\section{Positive and negative word of mouth}

In everyday language the word "recommendation" has positive connotations and is usually associated with transmission of favourable opinions about people or things. ${ }^{1}$ In marketing, we can distinguish both positive word of mouth (PWOM) and negative word of mouth (NWOM). In both cases we are dealing with the activity of potential, current or former clients who share their views about the company, product or service with others. The positive word of mouth, however, is the transfer of favourable opinions and negative word of mouth - the unfavourable opinions. While positive WOM (PWOM) is believed to be a result of satisfactory experiences, negative WOM (NWOM) is rather an outcome of motives and needs commonly identified as 'negativity bias' (Hornik, Satchi, Cesareo, Pastore, 2015, p. 273).

Negative recommendations usually work in opposition to positive suggestions. Studies have found largely positive consequences of PWOM for the evaluation of products and sales (e.g. East, Hammond, Lomax, 2008, pp. 215-224) and negative consequences of NWOM (e.g. Chen, Lurie, 2013, pp. 463-476). PWOM helps to attract new customers because of the reviews "from the outside", treated as a non-profit and independent of the company, which may be of interest or remove doubts in the decision-making process. Secondary (yet important) function of PWOM is to help customers moving up the ladder of loyalty (Kaniewska-Sęba, Leszczyński, 2017). NWOM may have a negative impact on the attitudes and purchasing decisions of customers, the company's image and can even lead - in a long-term perspective - to decrease in company value (BambauerSachse, Mangold, 2011, pp. 38-45; Verhagen, Nauta, Feldberg, 2013, pp. 1430-1440).

It should be noted, however, that consumers do not always respond to NWOM and PWOM in such an obvious way. In the literature, there are also considerations about a situation in which NWOM can cause positive effects, and PWOM can generate negative reactions of consumers (e.g. Berger, Sorensen, Rasmussen, 2010, pp. 815-827).

1 JP Dictionary defines it as "a written or oral positive opinion about someone or something; suggestion, recommendation, intercession". Rekomendacja, Stownik Języka Polskiego (Dictionary of Polish language, 2017). 
Both researchers and practitioners believe that the phenomenon of negative WOM is more influential than positive WOM (East, Hammond, Lomax, 2008, p. 215). Already in 1967 Arndt (1967, p. 292) argued that NWOM has two times more impact than PWOM. Previous studies have shown that negative information surprise the recipient more and, therefore, attract his attention to a greater extent (Xia, Bechwati, 2008, p. 5), spread faster (Libai, Muller, Peres, 2013, pp. 161-176) and are more influential (Chen, Wang, Xie, 2011, p. 31).

\section{WOM in social media}

WOM in social media (sWOM) is a social activity, where customers share their opinions and experiences with other members of the network through giving a "like", commenting and conducting discussions or transferring multimedia content to other network users. PWOM and NWOM are regular phenomena occurring in such communities and their content is visible to all its members.

Customer reviews can involve advertising or other activities in the field of marketing communications (ad eWOM), its offer (brand eWOM) or experience related to the purchase (purchase eWOM). Each of these types of WOM appears on different stages of the purchase funnel (Pauwels, Aksehirli, Lackman, 2016, p. 640). Ad WOM requires no prior purchase or consumption. Its source may be people who have never used the particular brand, but, for example, saw its advertisement in social media. Purchase WOM is the result of experiences during shopping (not necessarily concluded with the transaction), and the brand WOM is the result of actual feelings associated with usability of the brand.

The main differences between "traditional" WOM and its electronic form (including sWOM) are the range and sustainability of the opinions. The information that is being exchanged online is of unprecedented scale and detail (Libai, Muller, Peres, 2013, pp. 161-176; Lovett, Peres, Shachar, 2013, pp. 427-444). While verbal recommendations in the real world have a smaller range than those present in virtual environment (e.g. references on blogs or social networks), and are generally more volatile (because they are based primarily on the oral recommendations). It should be emphasized that a face-to-face recommendations at direct contact with other people, and therefore their opinions and reactions to them, are received verbally and nonverbally, e.g. through gestures, intonation of voice and attitude (Verhagen, Nauta, Feldberg, 2013). sWOM, on the other hand, includes simultaneous or non-simultaneous communication between network members using text and multimedia. This raises the question of whether the inability to express emotions in traditional, non-verbal way (and only through words, images, or smileys) does not make part of those emotions, especially the negative, being expressed in a more bluntly verbal manner?

WOM social media is a new form of electronic world of mouth (eWOM), in many respects similar to it, yet having its own specific characteristics. It is worth paying attention primarily to the social risk. Researches indicate that the transfer of negative word of mouth in social media can make the customers who generate this type of opinions be subjected to evaluation and assessment of other members of the network (see more: 
Eisingerich, Chun, Liu, Jia, Bell, 2015, pp. 120-128.). Therefore, before the client provides NWOM in social media, probably he will first consider the scale of social risk and therefore estimate the potential benefits and costs of such activity.

Basic differences between communication WOM, eWOM and sWOM have been presented in table 1.

Table 1

\section{Comparison between WOM, eWOM and sWOM}

\begin{tabular}{|c|c|c|c|}
\hline & WOM & eWOM & sWOM \\
\hline Mode & $\begin{array}{l}\text { Usually oral or verbal } \\
\text { One-to-one communica- } \\
\text { tion } \\
\text { Simultaneous communi- } \\
\text { cation }\end{array}$ & $\begin{array}{l}\text { Various online forms } \\
\text { One-to-one and one-to-many } \\
\text { communication } \\
\text { Simultaneous and non-simulta- } \\
\text { neous communication }\end{array}$ & $\begin{array}{l}\text { Social media platforms } \\
\text { One-to-one and one-to-many } \\
\text { communication } \\
\text { Mostly non-simultaneous com- } \\
\text { munication }\end{array}$ \\
\hline Receivers & Individuals & $\begin{array}{l}\text { Individuals, small groups or } \\
\text { public }\end{array}$ & $\begin{array}{l}\text { Individuals, social networks or } \\
\text { public }\end{array}$ \\
\hline Senders & $\begin{array}{l}\text { Identifiable and account- } \\
\text { able }\end{array}$ & Identifiable and unidentifiable & Identifiable and accountable \\
\hline Scope & $\begin{array}{l}\text { Geographical and tempo- } \\
\text { ral constrains }\end{array}$ & $\begin{array}{l}\text { Limited geographical and tem- } \\
\text { poral constrains }\end{array}$ & $\begin{array}{l}\text { Limited geographical and tem- } \\
\text { poral constrains }\end{array}$ \\
\hline $\begin{array}{l}\text { Connection be- } \\
\text { tween the receivers } \\
\text { and the senders }\end{array}$ & Strong ties & Strong or weak ties & $\begin{array}{l}\text { Combination of strong or weak } \\
\text { ties }\end{array}$ \\
\hline \begin{tabular}{|l|} 
Risk associated \\
with WOM
\end{tabular} & Low social risk & Low social risk & High social risk \\
\hline \begin{tabular}{|l} 
Speed of diffu- \\
sion
\end{tabular} & Slow & Fast & Fast \\
\hline
\end{tabular}

Source: Balaji, Khong, Chong (2016, p. 529).

\section{Negative recommendation in social media - case studies}

Issues connected with WOM and eWOM are a relatively popular topic of research in the area of marketing (see meta-analysys of De Matos, Rossi, 2008, pp. 578-596; Babic, Sotgiu, de Valck, Bijmolt, 2016, pp. 297-318; Floyd, Freling, Alhoqail, Cho, Freling, 2014, pp. 217-232; You, Vadakkepatt, Joshi, 2015, pp. 19-39). Furthermore, researchers are increasingly more interested in the phenomenon of WOM and NWOM in social media (e.g. Relling, Schnittka, Sattler, Johnen, 2016, pp. 42-58). However, there is little research that treat the subject in a holistic way and allow to understand not only the results, but also conditions behind communicating NWOM in social media (Balaji Khong, Chon 2016, pp. 528-540).

In Polish literature on marketing, the sWOM is still a relatively popular subject of study and analysis. Therefore, in the next part of this article the authors will present three case studies relating to the phenomenon of negative word of mouth on social media. The current authors referred to the most recent examples from the Polish market due to available access to online comments and observations of reaction of companies - brand owners, who find themselves in a crisis situation caused by NWOM. 
In the first half of 2017 we had to deal with three major crises of Polish brands associated with negative reactions of users in social media. Such a crisis has been suffered by: Orange (February), Reserved (March) and Staropolanka (May).

On 25th of February, the Orange Poland placed on its channel on YouTube an advertising spot promoting, among others, Orange Love tariff and the Orange Finances service. The video featured Agnieszka Jastrzębska - a journalist of breakfast television from TVN channel who presents show business news. She attempts to purchase a sweatshirt for PLN490, and when it turns out that she has not enough money she uses Orange services and takes a loan in the amount of PLN1000 spread into 36 instalments. Internet users quickly and very critically responded to this advertising spot. After the film met criticisms of the network users, the operator has marked the films as invisible a day after the criticism burst out (except for the spot described above, there appeared two other films maintained similar convention).

What were the objections of Internet users against this ad? They did not like, among others, the unreliability of the situation presented. It is hard to believe that the wellknown journalist cannot afford such a product ("You have a loan for an apartment, and you have a car. You even take a credit to go on vacation. TV, PC, PlayStation, and million other bullshit. Everything on a loan. Now it's time for a new level in this destructive game - buy yourself a shirt on a loan. Congrats to Orange"). Moreover, the ad suggested that the loan can be granted in a few seconds. Comments criticizing this aspect of advertisement appeared also on the Orange Poland fanpage: "As for the acceptance of a loan application in 2 seconds, you know how it really is. Sometimes it takes 15 minutes, sometimes an hour and sometimes you wait a week and at the end you get nothing"; "You advertise paying by phone, and uncoincidentally it was the iPhone 7. As of today, Apple Pay is not available in Poland. YOU MISINFORM YOUR CLIENTS. Sticking a proximity card onto the phone (together with a big Orange logo) does not make you able to pay with your phone. STILL it is a payment with a simple sticker (some time ago, the Polish PKO Bank was advertising proximity cards in the form of key fobs)." In this case, the criticism concerned the service, namely that the advertisement is misleading, suggests the product has properties which it does not have.

People did not like the unprofessional execution of the ad itself, the artificiality of the situation despite the assumed naturalness: "I have not seen something so hopeless for ages. terribly artificial. orange, have seen it at all?" "Well, we have the embarrassment of the year!", "how come that pseudo-journalist is promoted that much? The range of skills does not knock you down, she has nothing to offer except for some gossip and this glaring speech defect. Has anyone ever told her she is really annoying? I'm annoyed by people with a great urge to be on TV ... This is what the elites are supposed to be? Thank you very much! nc+ also went crazy with Cejrowski during the Oscars. This dude has just such a knowledge about movies that falls equally reliably as Jastrzebska in orange's spot." (after: Orange wycofat spot..., 2017).

Advertising has also been subjected to criticism by people running online blogs and websites devoted to advertising, which further increased the negative impact of the entire event. The "Advertising is exciting" blog fanpage run by Lukasz Mędrys includes the following: "Dear God, why? Why Jastrzębska? Why was it created? Why, Orange?" (facebook.com/excitingadvertising). Advertisement has also been analysed in the mate- 
rial entitled "Orange ashamed of its own advertising" prepared by Maciej Budzich of the Mediafun blog.

Orange decided to remove all three ads quickly (the most popular of them had more than 155 thousand views), indicating only that they were placed on the fanpage without consent of the marketing department. On Monday, two days after publishing the advertisements, Wojciech Jabczyński, a spokesman from the Orange Poland, said that the spot was put on air without the consent of the operator's marketing department and apologized for this premature publication.

The "Polish boy" campaign of Reserved brand took place a month later. It started in an unconventional way, namely with an American model searching for a Polish boy. On 17th of March there appeared a video on the Internet in which Dee Dee, a beautiful foreigner, is seeking Polish boyfriend named Votek. She was supposed to meet him at a concert in New Orleans. They were talking the whole concert, but at the end they lost each other in the crowd. The girl did not have any contact him, and the only thing she remembered was that he was wearing jeans, a jacket and white sneakers, his name is Votek and he is from Warsaw. At the end of the ad there is an appeal for help to find the boy and share the video with others. There is also an email address for those who would like to support the girl.

Internet users responded with great empathy, passed on the girl request and the video was receiving favourable comments. In the next cutscene, the girl thanked for the support and online assistance. She informed of numerous e-mails, pictures and even love letters received from the Polish guys. At the end she announced the good news - that she is going to Poland. In the third video, Dee Dee asks the band, which was giving the concert at the time she met the boy, to go to Poland and help in finding Votek. Despite some doubts, the band agrees and they together come to Poland. They give concerts on the street of Polish cities. At the end of a nearly four-minute video there is the pair, the band and the Reserved logo with the campaign hashtag \#polishboy.

Initially, the effects of the campaign were impressive. A significant reach has been built - the first video was viewed 1.7 million times in just five days. Despite doubts so as to its authenticity, which Maciej Budzich (an author of a marketing blog) has put forward, most people believed in this story and a large group became involved in helping with the search. The film has gained nearly 40 thousand likes (only 2000 negative reviews) and got nearly 5,000 comments. The action has also got media coverage - the material about searching for Polish boy was present in Teleexpres (a popular news programme broadcast on 5 p.m.), web portals, Gazeta Wyborcza newspaper and many other more or less serious placements such as gossip portals. No wonder that after the disclosure of the real purpose of the whole action, many involved has felt defrauded. There were opinions alleging the campaign creators of "playing on feelings", "fraud", "punching Poles in a bottle." The basic category, which emerges as a result of analysis of these comments, are the negative statements that allege of playing on feelings and using them for commercial purposes. The second group comprises unfavourable expressions, combined with the declaration to boycott products of the brand. The third category includes positive expressions that appreciate the idea behind the campaign (they a minority, though), while the fourth category concerns neutral feelings and the fifth - the negative responses that do not refer to the campaign itself or the brand. Comments from the latter category 
had racist overtones and referred to skin colour of the band members, who came with the girl to Poland ( "are those clothes for the black?", "what a pale face after seeing the rest of his family").

Table 2

The Reserved campaign - speech categories and examples of comments from given category

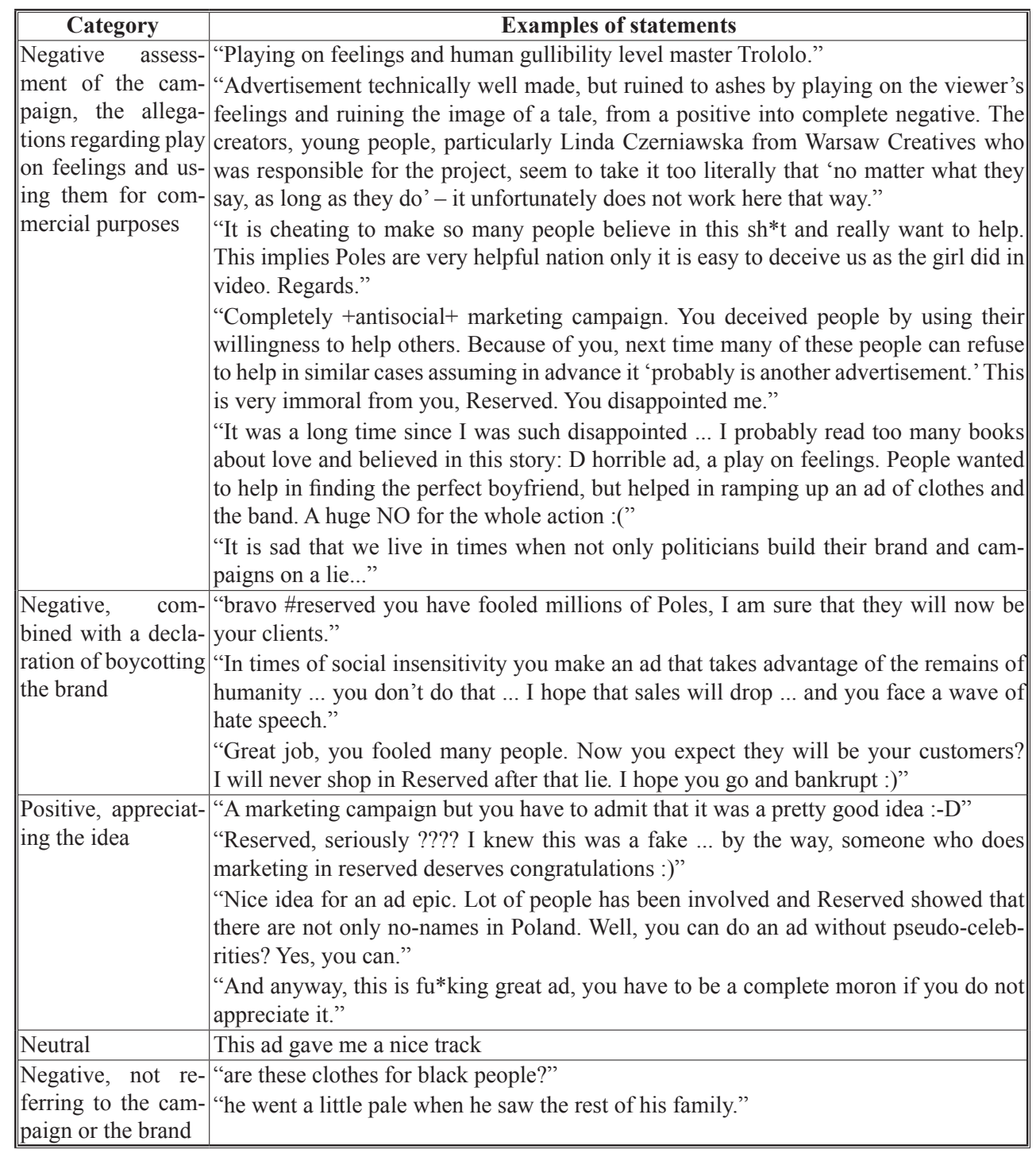

Source: Own studies based on analysis of comments from Reserved Facebook fanpage.

This campaign was also commented by those involved in the advertising and PR. Natalia Hatalska, a blogger, criticized the campaign because in her opinion it undermines public confidence which is already very low and "it bends the rules of the post-truth world." As she writes, "because of this, the Reserved campaign performed poorly. It un- 
dermines trust even more, although it is already reaching the lowest levels. Companies that want to "survive" in the world of post-truth cannot bend the truth even more. And although there are many campaign strategies and rules of conduct, the overriding principle for today is transparency, honesty and integrity" (Hatalska, 2017). Maciej Budzich (2017b, c) performed a thorough analysis of the campaign on his YouTube channel at first showing evidence indicating that it was fake, and later conducted an interview with its creators - Linda Czerniawska and Paweł Walicki of Warsaw Creatives agency. He primarily criticized the mechanism, on which the campaign is based and its effects. He used a parable about a boy who was waking up the whole village shouting "Fire!" which turned out to be untrue, but when real fire burst out, no one believed in the alarm. In his opinion, the Reserved campaign may suppress natural instincts of people who will be in a similar situation in the future and will not be so eager to help. Even more critical of the Polish boy campaign was Michał Szafrański, author of the blog entitled "How to save money", who states that "Reserved has fuc*ked us up a bit." He considered behaviour of the Reserved brand as cynical and as part of a protest against such actions in the future, he declared boycotting products of this brand.

Reserved thanked those who liked the idea for positive assessment. Adverse reactions have been considered as an expression of disappointment at the end of the campaign. The company did not apology for misleading Internet users, who were involved in the search. This is the original version of the statement:

"For a few days everyone was looking for the mysterious Wojtek. From where you took the idea for the action? To show that there are millions of such perfect young boys in Poland. The very fact that so many of you have been involved in helping DeeDee shows how GORGEOUS you are! That's why the \#POLISH BOY became the hero of our new campaign. We are sorry if some of you feel disappointed. For those who liked the idea - thank you for many likes. History of DeeDee was invented, but it could really happen! See our video".

At the beginning of May 2017, equally negative reactions were caused by cooperation between Staropolanka water and controversial clothing brand Red is Bad. ${ }^{2}$ Within 5 days from placing information about the campaign on Staropolanka fanpage $912 \mathrm{com}-$ ments were published. Many of them had a very negative character. Unfavourable assessments of the campaign were accompanied by declarations to resign from purchasing a brand that is promoted in this manner. The statements of this type feature negative, emotional phrases as well as labelling those who have different opinions: "Oh. I see you still stand your ground. Just keep on disgusting your water even more. Just on the National Flag day you endorse cooperation with a company that disgrace the Polish Coat of Arms, a fascist company which produces rags, rather than clothes. Who is in charge of your marketing and social media, are you serious? Since I was a kid I can remember Your water (born in 1983), but so be it: fascist water - I do not drink," "Watch out, do not drink this shit - my friend drunk Staropolanka and began to bald and he keeps talking about the great Catholic Poland - it is probably poisoned!!!"

${ }^{2}$ Red is Bad is a clothing brand, which except for putting imprints on their own clothes that refer to the events from Polish history, shows the anti-EU manifestos and inscriptions criticizing the leftist ecological movement. 
A large group, at some point comparable to the opponents of the campaign, defended the campaign idea pointing out that it promotes patriotism, not fascism or Nazism. Also the appropriateness and the strength of boycott of Staropolanka was argued. In this group there were also comments about frequent declarations of increased interest in the product being under the influence of this campaign: "Oh, and mister Marketing Specialist - 900 persons liked the Staropolanka boycott event (say: nine hundred). Even Cezik concert in Sopot had a wider audience. If this is a disaster within the brand image, it is you - the marketers - who are really needless"; "Come on, apologize to all those offended leftwing socialists for referring to national colours... if you make labels with Stalin or Che Guevara, perhaps the whole that advanced and enlightened European youth being free of racism, intolerance or fascism will be delighted."

On Staropolanka funpage, the campaign evoked a very emotional discussion. The topics quickly moved away from the core of the campaign and became the exchange of invectives between the supporters of the campaign (referred to by its opponents as nationalists) and its opponents (called the leftists). Here are few examples of this type of posts: "You look like a psycho who kills children before he rapes them and then eats them. But it is a rule among you, neo-communists. You are all alike with this madness in the eyes." In another statement of the discussion participant there is a reference to Staropolanka: "Definitely, the best water in Poland. Not only neo-communists, homosexuals, all sorts of degenerates, perverts, paedophiles and banned wombs are afraid of it as the devil of holy water 3 : D From now I do not drink anything else! Pain in the ass of Stalin's bastards is the best promotion in the trade ever. Thanks for the ad [ $U$. 'Stop water dictatorship!' Fuck it, I stop drinking! Die of thirst you communist sonsofbitches. As part of your protest just stop breathing this fascist air xD". It is also noticeable that the group includes several particularly active participants who become visible when negative opinions about the campaign appear.

Table 3

\section{The Staropolanka and Red is Bad campaign - speech categories and examples of comments from given category}

\begin{tabular}{|c|c|}
\hline Category & Examples of statements \\
\hline 1 & 2 \\
\hline $\begin{array}{l}\text { Negative appraisal } \\
\text { of the campaign, } \\
\text { accusations refer- } \\
\text { ring to relationship } \\
\text { with a brand which } \\
\text { produces clothes } \\
\text { that promote na- } \\
\text { tionalism }\end{array}$ & $\begin{array}{l}\text { "and the collector's edition with a brown glass for the rightists will be available?" } \\
\text { "Dear mother, now in spite of one of the best Polish mineral waters we will have a pro- } \\
\text { motion of homophobia, nationalism, assaults on people, racism, rudeness, lies and ex- } \\
\text { treme Catholicism? Do you really want to transform a decent brand into cooperation } \\
\text { with freeloaders and socially excluded?" } \\
\text { "What else you can do after creating such a mess, but still being a marketer from } \\
\text { a higher school of making noise? Turn off the possibility to add a rate and keep up with } \\
\text { this shit. I suspect that the campaign will be shown in marketing schools as a perfect } \\
\text { example that after a marketing shot right in the knee you can still finish yourself with } \\
\text { a headshot. Congrats. I believe it is a sparkling water?" } \\
\text { "Staropolanka advertises through a company that divides people into better and worse } \\
\text { Poles. I don't like it." } \\
\text { "The company picked up a very bad way for promotion - through cooperation with } \\
\text { a company which positions itself at the very right side of the political and social divi- } \\
\text { sions within out country. With this co-branding, Staropolanka has taken a position at one } \\
\text { side of the division, or even a conflict. Company has the right, but I must agree that }\end{array}$ \\
\hline
\end{tabular}




\begin{tabular}{|c|c|}
\hline 1 & 2 \\
\hline & $\begin{array}{l}\text { politicisation of mineral water is a masterpiece - not everyone can do that. Now many } \\
\text { of us will associate Staropolanka with a company that refuses to cooperate with the EU, } \\
\text { promotes nationalism and randomness at interpretation of history of our country. Not } \\
\text { to mention a fail which was to design a label in white and red colours with a the words } \\
\text { Red is Bad. Statement issued by Staropolanka did not make up for the mistakes, but it } \\
\text { rather drove made a great number of people. A total fail." } \\
\text { "Oh, I'm happy it is possible again to leave a rate. I think i prefer toilet water than } \\
\text { this water produced by a company that cooperates with nationalists, homophobes and } \\
\text { chauvinists. Frosty regards." }\end{array}$ \\
\hline $\begin{array}{l}\text { Negative, combined } \\
\text { with a declaration } \\
\text { of boycotting the } \\
\text { brand }\end{array}$ & $\begin{array}{l}\text { "I have never drunk Staropolanka. Now I won't buy this water which explicitly sup- } \\
\text { ports the far right ideology and in this way supports racism, xenophobia, homo-, } \\
\text { lesbo-, trans- and interphobia, misogyny, antisemitism and Catholic fanaticism. Gener- } \\
\text { ally we must boycott all companies and products they make which support discriminat- } \\
\text { ing and disgusting preferences. Are those frustrates, hypocrites and hateful people of } \\
\text { red is bad aware that the red colour which they hate and stereotypically associate with } \\
\text { communism constitutes a half of the Polish flag which they carry over streets promot- } \\
\text { ing hatred towards people... What a falseness and conceitedness!!!" } \\
\text { "Cooperation with a certain brand convinced me to stop buying this water... Fare- } \\
\text { well." } \\
\text { "I no longer buy it, my family no longer buys it. I don't know if it is a good idea to } \\
\text { discourage regular clients to the benefit of nationalists who prefer the cheapest beers } \\
\text { over water." } \\
\text { "Oh. I see you still stand your ground. Just keep on disgusting your water even more. } \\
\text { Just on the National Flag day you endorse cooperation with a company that disgrace the } \\
\text { Polish Coat of Arms, a fascist company which produces rags, rather than clothes. Who } \\
\text { is in charge of your marketing and social media, are you serious? I can remember Your } \\
\text { water since I was a kid (born in } 1983 \text { ), but so be it: Fascistowianka - I do not drink." } \\
\text { "Watch out, do not drink this shit - my friend drunk Staropolanka and began to bald and } \\
\text { he keeps talking about the great Catholic Poland - it is probably poisoned!!!" } \\
\text { "Seriously?! You have been criticized like never before and in spite of issuing a state- } \\
\text { ment, apologize or step back, you share your own post? Cheers for a good taste and } \\
\text { knowledge about social media. Of course I won't buy it anymore." } \\
\text { "You have reached the top level of stupidity. I suggest changing the brand name into } \\
\text { AllPolandka and emphasizing that it quenches thirst only among the pure nationalists. } \\
\text { Your water will NEVER find its place on my table..." } \\
\text { "A 'Nur für naziole' company? No, thank you." }\end{array}$ \\
\hline $\begin{array}{ll}\text { Positive } & \text { opinions } \\
\text { about the } & \text { campaign }\end{array}$ & $\begin{array}{l}\text { "Oh, and mister Marketing Specialist - } 900 \text { persons liked the Staropolanka boycott } \\
\text { event (say: nine hundred). Even Cezik concert in Sopot had a wider audience. If this is } \\
\text { a disaster within the brand image, it is you - the marketers - who are really needless." } \\
\text { "Come on, apologize to all those offended left-wing socialists for referring to national } \\
\text { colours... if you make labels with Stalin or Che Guevara, perhaps the whole that ad- } \\
\text { vanced and enlightened European youth being free of racism, intolerance or fascism } \\
\text { will be delighted." } \\
\text { "Thanks to this pseudo-boycott I took notice of the water and today during regular } \\
\text { shopping I choose it to fill my car trunk } \\
\text { boycotted by the leftists } \\
\text { "I will not know the brand if you didn't make the campaign. Thanks, now I will be } \\
\text { buying it "E::". } \\
\text { "Thanks to the patriotic marketing campaign you encouraged me to buy!" }\end{array}$ \\
\hline $\begin{array}{l}\text { Com m e n taries } \\
\text { which negatively } \\
\text { refer to criticism of } \\
\text { the campaign }\end{array}$ & $\begin{array}{l}\text { "You look like a psycho who kills children before he rapes them and then eats them. } \\
\text { But it is a rule among you, neo-communists. You are all alike with this madness in the } \\
\text { eyes." } \\
\text { "Definitely, the best water in Poland. Not only neo-communists, homosexuals, all sorts } \\
\text { of degenerates, perverts, paedophiles and banned wombs are afraid of it as the devil }\end{array}$ \\
\hline
\end{tabular}




\begin{tabular}{|c|c|}
\hline 1 & 2 \\
\hline & $\begin{array}{l}\text { of holy water } \\
\text { bastards is the best promotion in the trade ever. Thanks for the ad in the ass of Stalin's } \\
\text { "“Stop water dictatorship!' Fuck it, I stop drinking! Die of thirst you communist sonsof- } \\
\text { bitches. As part of your protest just stop breathing this fascist air xD." } \\
\text { "But you have never been buying this water, you distrustful leftist scum. Drink water } \\
\text { from a cesspool, maybe it will be less brown." }\end{array}$ \\
\hline
\end{tabular}

Source: Own studies based on analysis of comments from Staropolanka fanpage.

Experts in the field of advertising and marketing differently appraise the campaign idea as well. For instance, Zbigniew Lazar, an owner and directore of Modern Corp. agency and brand image specialist, believes that Staropolanka should not be worried of how the campaign has been received, especially that negative opinions do not refer to water quality. Furthermore, some of those opinions were inspired by the manner, in which certain media have presented the campaign (e.g. Gazeta Wyborcza). He also emphasizes that the campaign could be favourable for (through the so-called "aureole" phenomenon) Red is bad company, which has been a niche brand before. Similar arguments have been put forward by Marcin Kalkoffi and Witold Koroblewski. In their opinion, such an action can encourage some customers, while discourage others. Anyway, the visible benefit will be that the brand awareness among clients will improve. However, other specialists have different views. Michał Nowosielski, for instance, stated that the action implies unnecessary risk for the brand image of Staropolanka (Goczał, 2017).

A day after publishing the information about cooperation between the both brands (i.e. on 2 May 2017), the company posted a statement on its Facebook fanpage, in which it emphasizes business nature of the cooperation and denies its ideological characteristics. Text prepared by Staropolanka was exactly as follows: "Dear Customers, Staropolanka has been cooperating with numerous companies and entities since many years and produces for them limited series of mineral waters with the customer's logo that can be seen in hotels, restaurants and supermarkets. Cooperation with Red is Bad has a similar nature. It was not our intention to create ideology which you address in the commentaries. This is strictly business cooperation that aims at offering our customers a god quality water. We are very sad that many of you is looking for a double meaning. We are not disqualify anyone on grounds of their political views or preferences. We are occupied with production of water. Good water." The disallowed possibility to rate Staropolanka has been noticed and negatively commented by the Internet users as well.

\section{Summary and implications for managers}

Discussion included in the article has a contributing nature and constitutes an attempt to fill (at least partially) a knowledge gap about the NOWM phenomenon within social media. The presented theoretical deliberations and case studies show how difficult it is for managers to manage NWOM and its effects in social media. Specificity of how information about a company function in social media has been aptly characterized by Miller (2012, p. 46): "News in traditional media have been transferred to clients and then forgotten". Currently, they are subject to different principles. Any information can be 
transformed into a fierce discussion, which is independent of the original sender. Thanks to the virtual 'polyphony', the information can be counter effective to what its original sender (institution) had in mind. Moreover, due to such services like Internet Archive, which gather and store contents, the Internet memorizes everything forever." Hence, negative recommendation in social media can have a greater impact than a gossip that spreads by word of mouth due to enormous reach and pace of disseminating given information. The above should be also supplemented with multi-threading of the discussion. NWOM often comprises critical opinions about many aspects of a company.

What is more, the language of people who disseminate NWOM in social networks can also be a great challenge for the marketers. In this case, we can often talk about the hate speech. Illusive anonymousness and low level of social risk in social media increase the probability of noticing unfavourable and exaggerated opinions. Thus, it is possible that people who use hate speech would be likely to join the truly appalled or somehow offended clients. It is worth remembering that a confrontational response from the entity being criticized can intensify the whole problem and increase the power of unfavourable recommendations.

Hence, how should we deal with similar situations? When a similar situation uncovers, it is advised that the department responsible for external communication (e.g. the PR department) becomes involved. Social media is place of uncontrolled dialogue, thus we should not start solving a crisis situation from removal of negative comments. In spite of that it is better to answer the accusations in a quick and honest way. In many examples, managing crisis situation requires simple apologize and a promise to remedy for the situation. If an opinion-making entity (e.g. a well-known blogger) criticizes a product or a company, he or she should be presented with an official opinion. Lack of any response from the company will mean that it does not monitor the network and is unable to see the threat, which can lead to a crisis situation. Another mistake consists in issuing a statement and failing to answer questions and comments that arise in consequence (Miller, 2012, p. 51).

Budzich (2013) lists on his blog two examples of interesting responses of foreign brands to online critique, both of them are completely different from the Polish instances being analysed. When one of the Internet users has asked why McDonalds's hamburgers look differently on pictures and when served, the head of PR answered with a video that showed the whole process of making the picture and the reasons why they look differently from what is seen on the plate. On the other hand, the producer of Bodyform menstrual pads answered accusations of an online surfer with a video that was explaining doubts which the producer itself had in connection with information contained within the company's commercials (see also: Wyrzykowska, 2016).

Wołyniec-Sobczak (2015) presents three types of situations and the possible responses. The first case is a situation, in which we deal with a typical slander. A person or the competition disseminates information, which are not true. In this case, the best option is to talk with that person individually. What is more, it is good to inform the environment about the situation and prevent from disseminating dishonest information, preferably using social media or online media dedicated to the respective market branch. Public discussion and exchange of arguments should be avoided because such situations often create two opposing camps and exaggerate aggression. The second type of a crisis is 
a situation of infringing the right to company's image or other protected goods as well as breaking of intellectual property (such as copyrights or trademarks) as a result of actions taken by third persons or third parties. In this example, the best option would be to take advice of a lawyer, who can suggest further steps. The last types of a crisis concerns situations, when the fault is on our side. If that is the case, it is advised to act according to the 5P rule formulated by Regester i Larkin (2005): (1) Show a human face; (2) Confirm that the event actually took place and apologize; (3) Take action; (4) Make up for the losses; (5) Improve to avoid repeating the event.

\section{Bibliography}

Allport G. W., Postman L. J. (1947), The psychology of rumor, Holt, Rinehart \& Winstron, New York. Arndt J. (1967), Role of product-related conversations in the diffusion of a new product, "Journal of Marketing Research", vol. 4(3).

Babic A., Sotgiu F., de Valck K., Bijmolt T. H. (2016), The effect of electronic word ofmouth on sales: A meta-analytic review of platform, product, andmetric factors, "Journal of Marketing Research", vol. 53(3).

Balaji M. S., Khong K. W., Chong A. Y. L. (2016), Determinants of negative word-of-mouth communication using social networking sites, "Information \& Management", vol. 53.

Bambauer-Sachse S., Mangold S. (2011), Brand equity dilution through negative online word-of-mouth communication, "Journal of Retailing and Consumer Services", vol. 18 (1).

Berger J., Sorensen A. T., Rasmussen S. J. (2010), Positive effects of negative publicity: When negative reviews increase sales, "Marketing Science", vol. 29(5).

Budzich M. (2017a), Orange wstydzi się swoich reklam, http://www.mediafun.pl/, 30.04.2017.

Budzich M. (2017b), Dziewczyna szuka chłopaka z Polski. A jeśli to fake? Poszlaki, http://www.mediafun.pl/, 30.04.2017.

Budzich M. (2017c), Dziewczyna szuka chtopaka z Polski to reklama marki Reserved - rozmowa ze sprawcami całego zamieszania, http://www.mediafun.pl/, 30.04.2017.

Chen Y., Wang Q., Xie J. (2011), Online social interactions: A natural experiment on word of mouth versus observational learning, "Journal of Marketing Research", vol. 48(2).

Chen Z., Lurie N. H. (2013), Temporal contiguity and negativity bias in the impact of online word of mouth, "Journal of Marketing Research", vol. 50(4).

Childers T. L., Rao A. R. (1992), The influence of familial and peer-based reference groups on consumer decisions, "Journal of Consumer Research", vol. 19(2).

De Matos C. A., Rossi C. A. V. (2008), Word-of-mouth communications in marketing: A meta-analytic review of the antecedents and moderators, "Journal of Academy of Marketing Science", vol. 36(4).

DiFonzo N., Bourgeois M. J., Suls J. M., Homan C., Stupak N., Brooks B., Ross D. S., Bordia P. (2013), Rumor clustering, consensus, and polarization: Dynamic social impact and self-organization of hearsay, "Journal of Experimental Social Psychology", vol. 49(3).

East R., Hammond K., Lomax W. (2008), Measuring the impact of positive and negative word of mouth on brand purchase probability, "International Journal of Research in Marketing", vol. 27.

Eisingerich A. B., Chun H. H., Liu Y., Jia H. M., Bell D. J. (2015), Why recommend a brand face to face but not on Facebook? How word-of-mouth on online social sites differs form traditional word-of-mouth, "Journal of Consumer Psychology", vol. 25.

Floyd K., Freling R., Alhoqail S., Cho H. Y., Freling T. (2014), How online product reviews affect retail sales: A meta-analysis, "Journal of Retailing", vol. 90(2). 
Goczał B. (2017), Staropolanka na wspótpracy z Red Is Bad zyska popularność czy trwała rysę na wizerunku?, http://www.wirtualnemedia.pl/artykul/staropolanka-woda-z-red-is-bad-limitowanaedycja-zyska-popularnosc-czy-trwala-ryse-na-wizerunku-opinie, 2.05.2017.

Godes D., Mayzlin D. (2004), Using online conversations to study word-of-mouth communication, "Marketing Science", vol. 23(4).

Hatalska N. (2017), Nowa kampania Reserved i kryzys zaufania, http://hatalska.com/2017/03/22/nowakampania-reserved-i-kryzys-zaufania/, 5.05.2017.

Hornik J., Satchi R. S., Cesareo L., Pastore A. (2015), Information dissemination via electronic wordof-mouth: Good news travels fast, bad news travels faster!, "Computers in Human Behavior", vol. 45 .

Kaniewska-Sęba A., Leszczyński G. (2017), Pomiar marketing i sprzedaży business-to-business, Wyd. Nieoczywiste, Warszawa (w druku).

Katz E., Lazarsfeld P. F. (1955), Personal Influence; The Part Played by People in the Flow of Mass Communications, Free Press, Glencoe, Il.

Libai B., Muller E., Peres R. (2013), Decomposing the value of word-of-mouth seeding programs: Acceleration versus expansion, "Journal of Marketing Research", vol. 50(2).

Lovett L., Peres R., Shachar R. (2013), On brands and word-of mouth, "Journal of Marketing Research", vol. 50(4).

Meiners N. H., Schwarting U., Seeberger B. (2010), The renaissance of word-of-mouth marketing: A "new" standard in twenty-first century marketing management?!, "International Journal of Economic Science Research", vol. 3(2).

Miller G. (2012), Kryzys w mediach społecznościowych. Jak nim zarzqdzać?, in: Zarzqdzanie w sytuacjach kryzysowych niepewności, ed. K. Kubiak, Wyższa Szkoła Promocji, Warszawa.

Misner I. R. (1999), The World's Best Known Marketing Secret: Building Your Business with Word-ofMouth Marketing, 2nd ed., Bard Press, Austin, TX.

Narayan V., Rao V., Saunders C. (2011), How peer influence affects attribute preferences: A Bayesian updating mechanism, "Marketing Science", vol. 30(2).

Orange wycofat spot z Agnieszkq Jastrzębskq (2017), http://www.wirtualnemedia.pl/artykul/orangelove-finanse-usunal-spot-agnieszka-jastrzebska-pozyczka-bluza-iphone, 04.05.2017.

Regester M., Larkin J. (2005), Zarzadzanie kryzysem, PWE, Warszawa.

Pauwels K., Aksehirli Z., Lackman A. (2016), Like the ad or the brand? Marketing stimulates different electronic word-of-mouth content to drive online and offline performance, "International Journal of Research in Marketing", vol. 33.

Relling M., Schnittka O., Sattler H., Johnen M. (2016), Each can help or hurt: Negative and positive word of mouth in social network brand communities, "International Journal of Research in Marketing", vol. 33.

Rozin P., Royzman E. B. (2001), Negativity bias, negativity dominance, and contagion, "Personality and Social Psychology Review", vol. 5(4).

Szklarski M. (2014), Gwiazdy Internetu wedlug Trusted Trader, http://interaktywnie.com/forum/internet/badania-internetu/gwiazdy-internetu-2013-wg-trusted-trader-348, 10.052017.

Trusov M., Bucklin R. E., Pauwels K. (2009), Effects of Word-of-Mouth Versus Traditional Marketing: Findings from an Internet Social Networking Site, "Journal of Marketing", vol. 73.

Verhagen T., Nauta A., Feldberg F. (2013), Negative online word-of-mouth: Behavioral indicator or emotional release?, "Computers in Human Behavior", vol. 29(4).

Westrbrook R. A. (1987), Product/consumption-based affective responses and postpurchase processes, "Journal of Marketing Research", vol. 24(3).

Wołyniec-Sobczak I. (2015), Marka w kłopotach, czyli jak poradzić sobie w sytuacji kryzysowej, https:// sukcespisanyszminka.pl/marka-klopotach-czyli-poradzic-sytuacji-kryzysowej/, 2.05.2017. 
Wyrzykowska W. (2016), 5 blyskotliwych reakcji na kryzys w social mediach, http://www.brief.pl/ artykul,3778,5_blyskotliwych_reakcji_na_kryzys_w_social_media.html, dostęp 4.05.2017.

Xia L., Bechwati N. N. (2008), Word of mouse: The role of cognitive personalization in online consumer reviews, "Journal of Interactive Advertising", vol. 9(1).

You Y., Vadakkepatt G. G., Joshi A. M. (2015), A meta-analysis of electronic word-of-mouth elasticity, "Journal of Marketing", vol. 79.

\title{
Negatywna rekomendacja w mediach społecznościowych \\ - ujęcie teoretyczne i studia przypadków
}

\begin{abstract}
Streszczenie
Internet, w tym media społecznościowe, znacząco zmieniły sposób, w jaki konsumenci przekazują pozytywne bądź negatywne rekomendacje na temat produktów i usług. Rozwój mediów społecznościowych umożliwił szybsze dotarcie z takim komunikatem do znacznie większej liczby osób. Można również zaobserwować, że rozszerzył się zakres tematyczny komentarzy - klienci wypowiadają się nie tylko na temat jakości produktów, ich ceny, poziomu obsługi, ale także innych aspektów marketingowego funkcjonowania firm. W końcu, warto zwrócić uwagę na język owych opinii, który - w przypadku negatywnych doświadczeń z produktem, sprzedawcą czy reklamą - jest nierzadko agresywny.

Wraz z rozwojem i upowszechnianiem się sieci społecznościowych, menedżerowie ds. PR czy komunikacji marketingowej muszą nauczyć się jak komunikować się i z usatysfakcjonowanymi klientami i tymi, którzy na różnych etapach lejka zakupowego (purchase funnel) wyrażają swoje niezadowolenie. Jest to szczególnie ważne w przypadku neagative word of mouth (NWOM) bo każda negatywna opinia może stać się zalążkiem poważnej akcji kryzysowej i problemów wizerunkowych.

Celem artykułu jest ukazanie specyfiki word of mouth w mediach społecznościowych (sWOM) jako jednej z form elektronicznego WOM (eWOM) oraz zobrazowanie zjawiska negatywnej rekomendacji w social media na podstawie wybranych studiów przypadków z rynku polskiego.
\end{abstract}

Słowa kluczowe: rekomendacja (WOM), pozytywna rekomendacja (PWOM), negatywna rekomendacja (NWOM), media społecznościowe 